\title{
Evaluation of thermal behavior and chromatographic characterization of oil extracted from seed of Pittosporum undulatum
}

\author{
Marcelo Kobelnik ${ }^{1}$ - Gustavo Guadagnucci Fontanari ${ }^{2}$ - Clóvis Augusto Ribeiro ${ }^{3}$. \\ Marisa Spirandeli Crespi ${ }^{3}$
}

Received: 4 November 2016/Accepted: 10 October 2017/Published online: 23 October 2017

(C) Akadémiai Kiadó, Budapest, Hungary 2017

\begin{abstract}
The composition of the oil extracted from sweet pittosporum was studied by chromatography analyses. The sweet pittosporum (Pittosporum undulatum) is native to eastern parts of Australia. It is a tree growing to $15 \mathrm{~m}$ tall with wavy (undulating) leaf edges and also has attractive fragrant flowers, sweet pittosporum and is found in southern Brazil. The chromatographic profile of this oil reveals a predominance of unsaturated fatty acids, in particular, $28.86 \%$ of cis-11-eicosenoic acid (C20:1), 31.44\% of eicosatrienoic acid (C20:3n3), 6.61\% of docosahexaenoic acid (C22:6n3) and $24.32 \%$ of oleic acid (C18:1n9). This oil was characterized by differential scanning calorimetry (DSC), from 100 to $-80{ }^{\circ} \mathrm{C}$ and subsequently heated from $-80{ }^{\circ} \mathrm{C}$ up to $100{ }^{\circ} \mathrm{C}$, both at cooling/heating rate of 1 and $10^{\circ} \mathrm{C} \mathrm{min}^{-1}$. Thermogravimetry (TG) and differential thermal analysis (DTA) in nitrogen and oxygen purge gases under different heating rates show oil stability. The analysis carried out by DSC indicates that this oil has two crystallization peaks under cooling condition. Simultaneous TG-DTA curves show that the behavior of this oil
\end{abstract}

Marisa Spirandeli Crespi

crespims@iq.unesp.br

Marcelo Kobelnik

mkobelnik@gmail.com

Gustavo Guadagnucci Fontanari

gufontanari@gmail.com

1 University Center of North Paulista (UNORP), São José do Rio Preto, SP, Brazil

2 Faculty of Public Health, University of São Paulo (FSP/USP), São Paulo, Brazil

3 São Paulo State University (UNESP), Chemistry Institute, Rua Professor Francisco Degni,55, Araraquara, SP 14800-900, Brazil shows variation among the heating rates, with a sudden combustion. The kinetic behavior showed the relationship between the uses of two sample masses, with good parameter and high correlation coefficients $(r)$.

Keywords Sweet pittosporum oil - Thermal behavior . Chromatographic analysis

\section{Introduction}

Sweet pittosporum (Pittosporum undulatum) is native to eastern parts of Australia. It is a tree growing to $15 \mathrm{~m}$ tall with wavy (undulating) leaf edges and also has attractive fragrant flowers, sweet pittosporum [1]. It is known as an invader of many tropical and subtropical mountain forests and in warm temperate regions of both hemispheres and many islands. The fruits have diameter between 1 and $1.5 \mathrm{~cm}$ and are orange capsules and when ripe they became sticky and possess a strong odor [2]. This tree has been introduced widely as an ornamental plant to North America, southern Brazil, and also in Africa. In Brazil, this species was introduced for ornamental purposes and also used for afforestation purpose in public way, but because of its extremely rapid growth, it turned into invasive species $[3,4]$.

The composition of leaves of sweet pittosporum has been studied and analyzed, were has been found several terpenoids. Higuchi et al. relate the deacylsaponin and the A1-barrigenol 3-O-glycoside, while Mendes et al. extracted the essential oils of the fruits of this tree with methanol $(\mathrm{MeOH})$, and the results show that there are two types of sequiterpenes, namely 4-guaiene-11- $O$-b-D-(30-angeloxy60-deoxy)-glucopyranoside and 1(5)-guaiene-11- $O$-b-D(30-angeloxy-60-deoxy)-glucopyranoside [5, 6]. Moreover, 
essential oils extracted from sweet pittosporum leafs were characterized in order to determine the volatiles chemical diversity in this species in Azorean islands, and one of the aims of this study was to determine the chemical composition to establish the volatiles products [7].

Therefore, the exploration of new sources of seed oils has presented a great advance due to the possibility to find new fatty acids with high levels of polyunsaturated with high concentrations of the long-chain fatty acids. Thus, the main objective of this work is to contribute to the study of oils present in seeds found in Brazil to show the chemical composition and thermal properties of this new oil. The present investigation reports the chromatographic characterization and thermogravimetric (TG/DTG) and calorimetric (DSC) evaluations of the oil extracted from fruits of sweet pittosporum (Pittosporum undulatum). Additionally, the thermal behavior and kinetic evaluations of this oil by TG curves were made with two different mass samples under nitrogen and oxygen purge gases.

\section{Experimental}

\section{Materials}

The sweet pittosporum (Pittosporum undulatum) was obtained from Ivaí city $\left(25^{\circ} 00^{\prime} 39^{\prime \prime} \mathrm{S}, 50^{\circ} 51^{\prime} 32^{\prime \prime} \mathrm{W}\right)$, Paraná state, Brazil. Mature fruits were collected, cooled, and subsequently submitted to a manual pulp removal process and then dried at room temperature. The seeds were grounded in a domestic blender, homogenized and sieved (0.42 $\mathrm{mm}$ mesh) resulting in flour which was mixed with $n$-hexane (analytical reagent) in an extraction bath at ambient temperature to avoid the oxidation of the obtained oil. Posteriorly, the mixture was filtered in a qualitative paper filter (Whatman $125 \mathrm{~mm}$, no. 1), and the $n$-hexane phases were removed and concentrated in a rotary evaporator.

\section{Methods}

The method described below and used in this work on the chromatographic analysis, thermal analysis, and kinetic evaluation was widely exposed in other work carried out. Thus, it should be noted that this is not a self-plagiarism but is aimed at the use of a standard methodology. Therefore, the use of standard analysis is a practical basis that allows to reproduce the results obtained by other research groups without the need to complicate the understanding of extraction procedures and analysis.

\section{Lipid profile}

The fatty acid profiles of the oils extracted from the flours were determined using the method of Folch et al. [8], followed by lipid methylation to produce fatty acid methyl esters according to Hartman and Lago [9]. The fatty acid determination was carried out on GC-2010 Gas Chromatograph Shimadzu, Tokyo, Japan, fitted with an SP2560fused silica column $(100 \mathrm{~m} \times 0.25 \mathrm{~mm}$ I.D., film thickness $\times 0.20 \mu \mathrm{m}$ by Supelco). The oven temperature was programmed to rise from 100 to $235{ }^{\circ} \mathrm{C}$ at the rate of $10{ }^{\circ} \mathrm{C} \mathrm{min}-1$ under the following conditions: carrier gas $\mathrm{H}_{2}$ $\left(2.5 \mathrm{~mL} \mathrm{~min}^{-1}\right)$, split ratio 50:1, flame ionization detector (FID) $250{ }^{\circ} \mathrm{C}$. Thus, the peaks of fatty acids were identified by comparing the retention time of a standard mixture of fatty acid methyl esthers (37 FAME Mix 47,885, Supelco). The area of each peak was expressed as a percentage in the chromatogram.

\section{Thermal methodology}

TG/DTG curve measurements were performed in a SDT 2960, from TA Instruments, with sample masses of 5 and $20 \mathrm{mg}$, both in platinum crucible with heating rates of de 5 , 10 , and $20{ }^{\circ} \mathrm{C} \mathrm{min}^{-1}$. Nitrogen and oxygen were used as purge gas to perform the TG curves with the flow rate of $100 \mathrm{~mL} \mathrm{~min}^{-1}$. The phase transition evaluation was performed by DSC evaluation. The measurements were obtained from DSC1 $\mathrm{Star}^{\mathrm{e}}$ (Mettler Toledo) with a mass sample around $5 \mathrm{mg}$ in the aluminum crucible. The samples were cooled from 100 to $-80^{\circ} \mathrm{C}$ and subsequently heated from $-80{ }^{\circ} \mathrm{C}$ up to $100{ }^{\circ} \mathrm{C}$, both at cooling/heating rate of 1 and $10{ }^{\circ} \mathrm{C} \mathrm{min}-1$ under nitrogen as a purge gas at the flow rate of $50 \mathrm{~mL} \mathrm{~min}{ }^{-1}$. Furthermore, in the kinetic study, this work adopted the isoconversional method as a way to avoid the use of explicit kinetic models as mentioned in previous works [10-15]. Then, in this work, the kinetic parameters were obtained using the approximation to the integral temperature based on the Jacobi fraction, as proposed by Capela and Ribeiro [16].

Also, the ICTAC Kinetics Committee has recommended conditions to obtain kinetic data for thermoanalytical curves [17]. It is important to note that this Committee suggests three or more curves, because it has been considered that statistics require three minimal quantities of TG curves. We also consider being appropriate to use more than one sample mass and also purge gas to promote a better interpretation of kinetic data as much as possible, as carried out in others works, where was possible to see the results obtained with different conditions of analysis [18-21]. 


\section{Results and discussion}

\section{Chromatography analysis and thermal cooling}

The amount of oil extracted was about $13.8 \%$ by mass of the sample. At room temperature, the oil has a yellow color and characteristic odor, what is known in Brazil as the scent of incense. The lipid profile of this oil is shown in Table 1, where it is possible to see that this oil is predominantly composed of unsaturated fatty acids, representing around $96 \%$ of the total composition. The present analysis shows the presence of cis-11-eicosenoic (C20:1), eicosatrienoic, and docosahexaenoic acids which has not been reported by us earlier. Also, the results indicate the presence of cis-11-Eicosenoic acid, which is a fatty acid, also called as gondoic acid that is found in a variety of plant oils and seeds, as in the seed of the Simmondsia chinensis (jojoba) plant $[22,23]$. However, the sweet pittosporum oil fatty acid can have in nature phytochemicals molecules, which can be a health hazard to humans, due the presence of trypsin, phenolics, lectin, among others, and therefore, this oil can be used for consuming, but after the elimination of the toxic antinutrients molecules [24, 25].

Based on the chain length and degree of unsaturation of the fatty acids, especially that fatty acids on the 3 and 6 positions have a great dietary importance in human foods, as suggested by Yamanaka et al. They consider the polyunsaturated fatty acids, having a carbon chain length of 18,20 , or 22 carbons, with 2 to 6 interrupted unsaturated bonds (cis configuration) [26, 27]. Nevertheless, many fatty acids were not found in significant quantities in the human body. As example, the eicosatrienoic acid (C20:9:n3), that was taken as a biochemical essential fatty acid, that had inhibitory effects on angiogenesis, shows in carried out study with cell culture system [28, 29], but however, your derivate $(\mathrm{C} 20: 3: n 3)$ does not exist in animal tissues to any appreciable extent, according indicate by Hamazaki et al. [30].

The docosahexaenoic acid (DHA), with 22 carbons and six double bonds, is an omega-3 polyunsaturated fatty acid, which found in fish and marine oils. This fatty acid also is

Table 1 Fatty acid composition of sweet pittosporum oil

\begin{tabular}{lr}
\hline Fatty acid & Mean value $^{\mathrm{a}} / \%$ \\
\hline Palmitic (C16:0) & $3.94 \pm 0.24$ \\
Oleic (C18:1n9) & $24.32 \pm 0.38$ \\
Linoleic (C18:2n6) & $5.26 \pm 0.09$ \\
cis-11-Eicosenoic acid (C20:1) & $28.86 \pm 0.62$ \\
Eicosatrienoic acid (C20:3n3) & $31.44 \pm 0.55$ \\
Docosahexaenoic (C22:6n3) & $6.61 \pm 0.44$
\end{tabular}

${ }^{\mathrm{a}}$ Mean standard deviation essential for normal brain growth and cognitive functions, and besides, been associated with neural development, with decreasing incidence of cardiovascular disease and other diseases [31, 32].

Essential fatty acids can be used as raw material for supplements, in functional food products fortified with lipids, which are currently available in the market to meet consumer demands or as beneficial to various materials such as creams, cosmetics, and therapeutic medicine [33]. Therefore, the evaluation of crystallization temperature and melting point of fatty acids is important. Due to the several compositions of fatty acids of this oil, in this work, the sample was subjected to a cooling and heating scans, with heating rates of 1 and $10^{\circ} \mathrm{C} \mathrm{min}{ }^{-1}$. Figure 1 shows these evaluations, where it is possible to see the typical DSC curves with a sample mass of $5 \mathrm{mg}$. For analysis with $10{ }^{\circ} \mathrm{C} \min ^{-1}$, during the cooling, two thermal events can be observed: (1) the first sharp exothermic peak between -18 and $-35{ }^{\circ} \mathrm{C}$, (2) it is possible to see a change in base line, around -37 and $-52{ }^{\circ} \mathrm{C}$, which was attributed to the crystallization of the eicosatrienoic acid (C20:3n3) and docosahexaenoic (C22:6n3), respectively. Now, for analysis in cooling rate of $1{ }^{\circ} \mathrm{C}$, it is possible to relate three events: (3) the first between 25 and $8{ }^{\circ} \mathrm{C}$; (4) second between -8 and $-29^{\circ} \mathrm{C}$; (5) third between -29 and $-45^{\circ} \mathrm{C}$. The first event may be related to overlapping reactions, to both samples, oleic and cis-11-Eicosenoic acids, while the second and third are linked with the same suggestion made by the analysis of $10^{\circ} \mathrm{C} \mathrm{min}^{-1}$.

During the heating stage, for $10{ }^{\circ} \mathrm{C} \mathrm{min}^{-1}$, it is possible to observe two broad endothermic events between -44

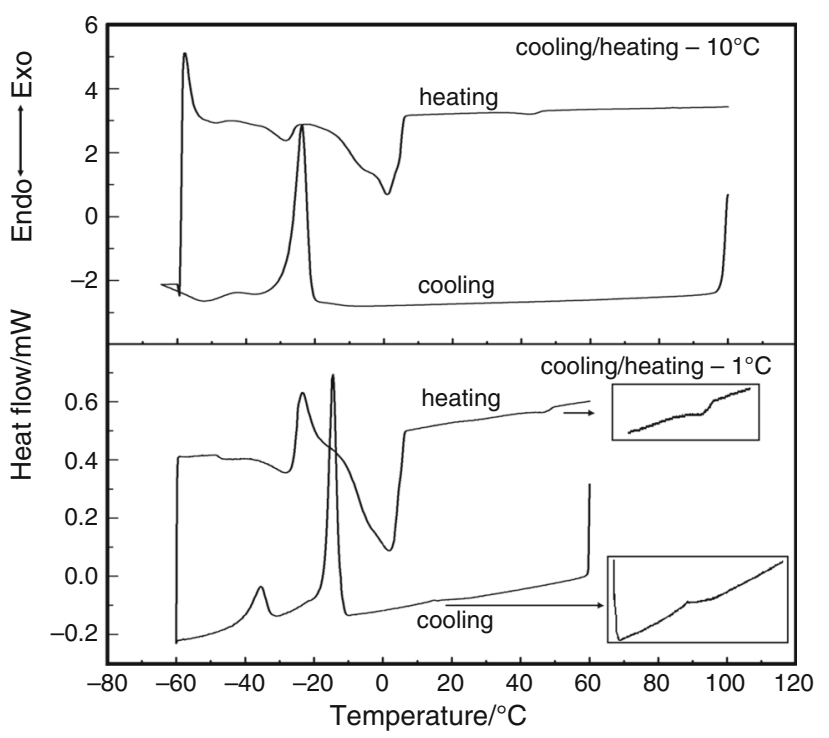

Fig. 1 DSC curves of sweet pittosporum oil under cooling and heating rate of 1 and $10^{\circ} \mathrm{C} \mathrm{min}-1$, with sample mass of $5 \mathrm{mg}$ in aluminum crucible under nitrogen purge gas 
and $-24{ }^{\circ} \mathrm{C}$ and also between -22 and $7{ }^{\circ} \mathrm{C}$. Additionally, there is a weak third event between 38 and $48{ }^{\circ} \mathrm{C}$. Now, with the analysis of $1{ }^{\circ} \mathrm{C} \mathrm{min}{ }^{-1}$, it is possible to evaluate that there were other reactions, namely (1) the first between -50 and $-45^{\circ} \mathrm{C}$; (2) the second between -39 and $-26^{\circ} \mathrm{C}$; (3) the third between -26 and $-16^{\circ} \mathrm{C}$ (exothermic peak); (4) the fourth between -16 and $8{ }^{\circ} \mathrm{C}$; finally, (5) the fifth between 39 and $52{ }^{\circ} \mathrm{C}$. These reactions, except to that one that occurs with exotherm peak, may be related to the relaxation solid-liquid of different fatty acids present in this oil during heating, which can be suggested to the following order: Docosahexaenoic (first), Eicosatrienoic acid (second), Linoleic, Oleic, and cis-11-Eicosenoic acids with the fourth interval and Palmitic with the fifth interval. Generally, the solid-liquid transitions are complex reactions because the present fatty acids may have more than one phase transition, which hampers the interpretation of the DSC curves. Usually, polymorphism occurs in the following order, $\alpha, \beta^{\prime}$, and $\beta$, which is attributed to increased melting temperature, as described by us and also for other authors [10, 12, 13, 15, 34-36]. Nevertheless, according to Rao, the endothermic reactions are $\alpha$ and $\beta$ transitions, while the exothermic reaction can be attributed to $\alpha$ transition to $\beta$, where a molecular rearrangement occurs during heating. Therefore, it was not possible to observe that this oil has an absolute value of the melting point, due the several mixtures of fatty acids. In addition, it is well known that unsaturated fatty acids have lower melting points than the saturated fatty acids. This fact occurs because the molecular geometries for saturated fatty acids that are relatively linear although with zig-zags, while that the introduction of one or more double bonds in the hydrocarbon chain results in one or more "bends" in the molecule. As the geometry of the double bond is almost always a cis configuration in natural fatty acids, the intermolecular interactions are much weaker than saturated molecules. Then, as a result, the melting points are much lower for unsaturated fatty acids, and in general, the melting point decreases with an increasing number of isolated cis-double bonds. Table 2 indicate the several melting points of some fatty acids, included the showed in this work, as shown by several authors [37-39]. It should be noted that the melting point of eicosatrienoic acid $(\mathrm{C} 20: 3 n 3)$ was not found in the literature and therefore is not displayed (this omitted) in Table 2.

\section{Thermal decomposition}

The TG/DTG curves under nitrogen and oxygen purge gases with a mass of 5 and $20 \mathrm{mg}$ and heating rate of $10{ }^{\circ} \mathrm{C} \mathrm{min}-1$ are showed in Fig. 2a, b, while Table 3 shows the mass losses. The thermal profile for $5 \mathrm{mg}$ under oxygen indicates that the initial thermal decomposition
Table 2 Configuration/position and melting points of fatty acids

\begin{tabular}{ll}
\hline Fatty acids & Melting point $/{ }^{\circ} \mathrm{C}$ \\
\hline Palmitic (C16:0) & 62 \\
Stearic acid (18:0) & 69 \\
Elaidic acid (18:1n9) & 46 \\
cis-2-Octadecenoic acid (18:1n2) & 51 \\
Oleic acid (18:1n9) & 13.4 \\
Linoleic acid (18:2n2) & -5 \\
Linolelaidic acid (18:2n2) & 28 \\
$\alpha$-Linolenic acid (18:3n3) & -11 \\
Arachidic acid (20:0) & 75.4 \\
Arachidonic acid (20:4n4) & -49.5 \\
Linoleic $(\mathrm{C} 18: 2 n 6)$ & $-5{ }^{\circ} \mathrm{C}$ \\
Oleic (C18:1 $n 9)$ & $14{ }^{\circ} \mathrm{C}$ \\
cis-11-Eicosenoic acid $(\mathrm{C} 20: 1)$ & $24{ }^{\circ} \mathrm{C}$ \\
Eicosatrienoic acid $(\mathrm{C} 20: 3 n 3)$ & - \\
Docosahexaenoic $(\mathrm{C} 22: 6 n 3)$ & $-45{ }^{\circ} \mathrm{C}$ \\
\hline
\end{tabular}

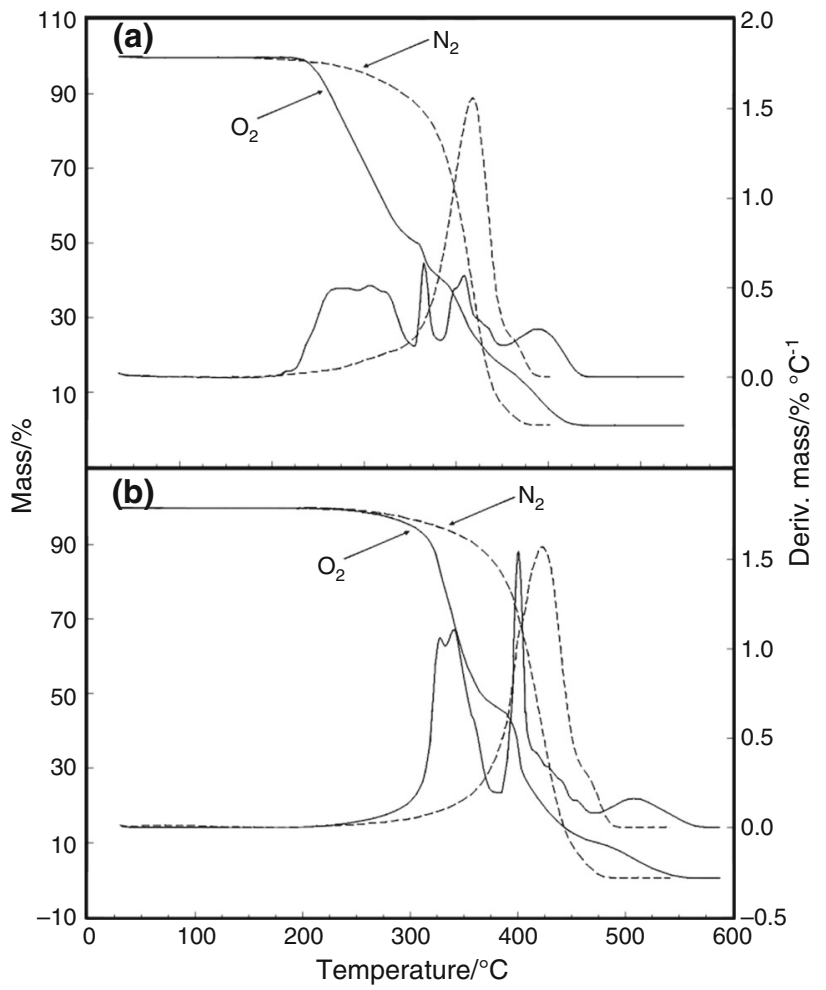

Fig. 2 TG/DTG curves of sweet pittosporum oil under oxygen and nitrogen purge gas, with heating rates of $10{ }^{\circ} \mathrm{C} \min ^{-1}$, sample mass of $5 \mathrm{mg}$ in platinum crucible

occurs after $215{ }^{\circ} \mathrm{C}$, with the DTG curve showed that thermal decomposition occurs in fourth stages, which occurs as overlapping reactions. The analyses with $20 \mathrm{mg}$ 
Table 3 Mass losses under nitrogen and oxygen purge gases, $\left(100 \mathrm{~mL} \mathrm{~min}{ }^{-1}\right)$, with heating rate of $20^{\circ} \mathrm{C} \mathrm{min}^{-1}$

\begin{tabular}{lllc}
\hline Mass and purge gas & Stage & $\Delta T /{ }^{\circ} \mathrm{C}$ & Mass loss/\% \\
\hline Oxygen 5 mg & 1 & $215-353$ & 49.65 \\
& 2 & $353-382$ & 9.96 \\
& 3 & $382-447$ & 22.96 \\
Oxygen 20 mg & 4 & $447-546$ & 16.65 \\
& 1 & $220-383$ & 53.81 \\
Nitrogen 5 mg & 2 & $383-468$ & 35.29 \\
& 3 & $468-574$ & 10.03 \\
Nitrogen 20 mg & 1 & $190-341$ & 9.09 \\
& 2 & $341-457$ & 85.57 \\
& 3 & $457-489$ & 3.66 \\
& 2 & $190-318$ & 4.18 \\
& 3 & $318-463$ & 91.21 \\
& 2 & $463-490$ & 3.70 \\
\hline
\end{tabular}

(Fig. 2b), still under oxygen, show that there are three main reactions during thermal decomposition. The first stage occurs between 220 and $383{ }^{\circ} \mathrm{C}$, the second stage occurs between 383 and $468{ }^{\circ} \mathrm{C}$, which shows a sharp peak, and in end of the reaction it has overlapping reactions, and the third stage $\left(468-574{ }^{\circ} \mathrm{C}\right)$ is due to the final residues of the material.

According to the DTG curves for analysis in nitrogen purge gas with sample of $5 \mathrm{mg}$, it can be seen that the thermal events start from $190{ }^{\circ} \mathrm{C}$ in a continuous reaction up to $341{ }^{\circ} \mathrm{C}$, which was attributed to the volatiles molecules, specifically known in food analysis as "smoke point." The same behavior also can be seen in DTG curve with the sample mass of $20 \mathrm{mg}$, but between interval of 190 and $318^{\circ} \mathrm{C}$, while the second stage occur between 317 and $493{ }^{\circ} \mathrm{C}$, without the formation of carbonaceous residue. Besides, simultaneous TG-DTA analysis under oxygen purge gas, with sample mass of 5 and $20 \mathrm{mg}$ and heating rates of 5,10 , and $20^{\circ} \mathrm{C}$, is shown in Fig. 3a, b, respectively. The result shows that the thermal behavior, individually, of $5 \mathrm{mg}$ that does not there were changes in the profiles of curves, while that with the increase of the mass to $20 \mathrm{mg}$ there was changes. As it is possible to see in DTA curves, the behavior of the oil shows variation among the heating rates, with a sudden combustion for heating of $20^{\circ} \mathrm{C} \mathrm{min}^{-1}$ in $303{ }^{\circ} \mathrm{C}$, which can be observed in the alterations of the TG and DTA curves. In analysis of $5 \mathrm{mg}$ and with heating rates of 5,10 , and $20^{\circ} \mathrm{C} \mathrm{min}{ }^{-1}$ and for 5 and $20{ }^{\circ} \mathrm{C} \mathrm{min}-1$ of the sample of $20 \mathrm{mg}$, the DTA curves show that the thermal decomposition is an exothermic reaction (without combustion).

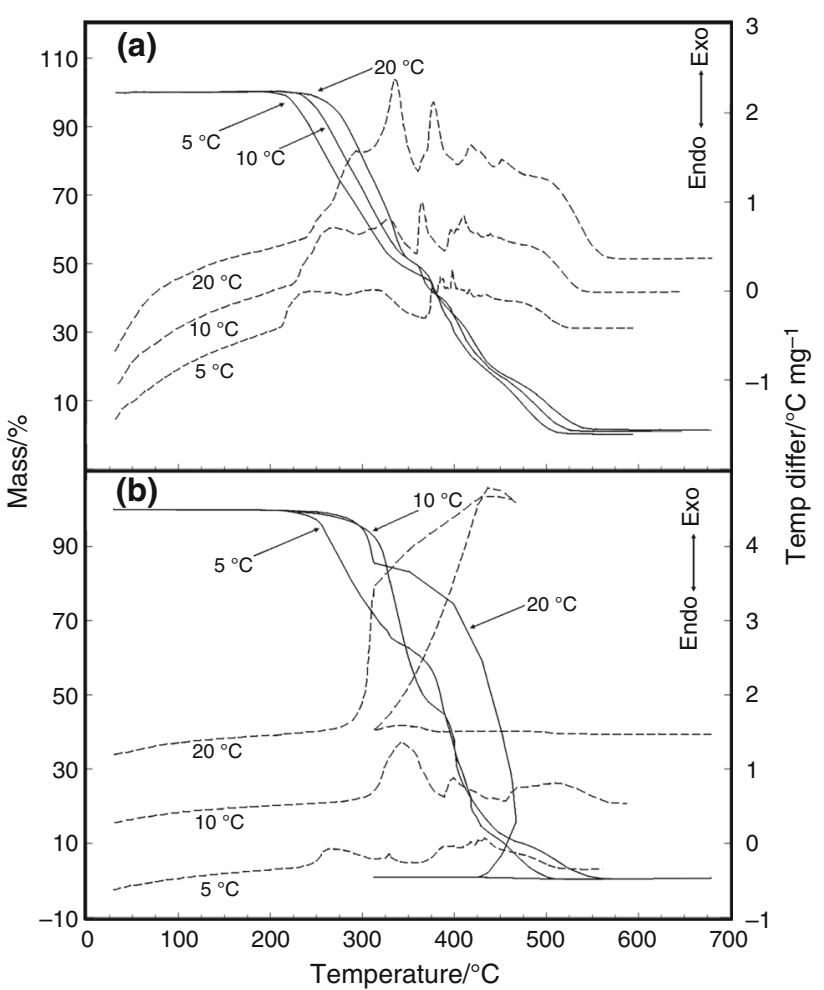

Fig. 3 TG/DTA curves of sweet pittosporum oil under oxygen purge gas, with heating rates of 5,10 , and $20{ }^{\circ} \mathrm{C} \mathrm{min}{ }^{-1}$, sample mass of $5 \mathrm{mg}$ (a) and $20 \mathrm{mg} \mathrm{(b),} \mathrm{both} \mathrm{in} \mathrm{platinum} \mathrm{crucible}$

\section{Kinetic evaluation}

Table 4 provides the average of the activation energy and also the linear correlation obtained for the two mass samples in oxygen and nitrogen purge gas and also the temperature intervals in DTG curves that were used for obtaining the kinetic data. The TG/DTG curves in nitrogen and oxygen gases are shown in Figs. 4, 5. Figure 4a, b, shows that the decomposition thermal of this oil occurs with three stages for 5 and $20 \mathrm{mg}$, which are indicated in Table 2 (only for heating rate of $10{ }^{\circ} \mathrm{C} \min ^{-1}$ ). For kinetic evaluation, the intervals used to both sample were excluded the initial interval of temperature and also the final intervals, according to Table 2. In fact, considering the effect of "smoke point", as aforementioned, the use from these intervals to evaluation of the kinetic data, can bring deformations in the activation energy data as determine the exact range of the smoke point and the effective thermal decomposition is difficulted. Then, a good parameter should have high correlation coefficients $(r)$, as shown in Table 2 , which has a relationship between activation energy and conversion degree $[40,41]$. These values are satisfactory for the sample mass of 5 and $20 \mathrm{mg}$ under nitrogen gas, but showed decrease for oxygen gas with $5 \mathrm{mg}$, which attributed to the overlapping reactions, as verified in intervals used (Table 4) and also to see in Fig. 5a, b. Besides, for oxygen analysis 
Table $4 E_{\mathrm{a}} / \mathrm{k} \mathrm{mol}^{-1}$ and correlation coefficient $(r)$ for the thermal decomposition stages

\begin{tabular}{|c|c|c|c|c|}
\hline Compound & Sample mass and purge gas & Temperature ranges (DTG curves) & $E_{\mathrm{a}} / \mathrm{kJ} \mathrm{mol}^{-1} *$ & $\overline{\text { correlation coefficient }(r)}$ \\
\hline \multirow[t]{10}{*}{ Sweet pittosporum } & \multirow[t]{3}{*}{ (Nitrogen) $5 \mathrm{mg}$} & $\left(5^{\circ} \mathrm{C}\right) 327-446{ }^{\circ} \mathrm{C}$ & \multirow{3}{*}{$163.31 \pm 0.03$} & \multirow{3}{*}{0.9999} \\
\hline & & $\left(10^{\circ} \mathrm{C}\right) 343-458^{\circ} \mathrm{C}$ & & \\
\hline & & $\left(20^{\circ} \mathrm{C}\right) 360-475^{\circ} \mathrm{C}$ & & \\
\hline & \multirow[t]{3}{*}{ (Nitrogen) $20 \mathrm{mg}$} & $\left(5^{\circ} \mathrm{C}\right) 337-446{ }^{\circ} \mathrm{C}$ & \multirow[t]{3}{*}{$161,68 \pm 0.03$} & \multirow[t]{3}{*}{0.99998} \\
\hline & & $\left(10^{\circ} \mathrm{C}\right) 359-462^{\circ} \mathrm{C}$ & & \\
\hline & & $\left(20^{\circ} \mathrm{C}\right) 379-479^{\circ} \mathrm{C}$ & & \\
\hline & \multirow[t]{3}{*}{ (Oxygen) $5 \mathrm{mg}$} & $\left(5^{\circ} \mathrm{C}\right) 209-279^{\circ} \mathrm{C}$ & \multirow[t]{3}{*}{$60.64 \pm 0.22$} & \multirow[t]{3}{*}{0.99336} \\
\hline & & $\left(10^{\circ} \mathrm{C}\right) 222-280{ }^{\circ} \mathrm{C}$ & & \\
\hline & & $\left(20^{\circ} \mathrm{C}\right) 240-308^{\circ} \mathrm{C}$ & & \\
\hline & (Oxygen) $20 \mathrm{mg}$ & - & - & - \\
\hline
\end{tabular}

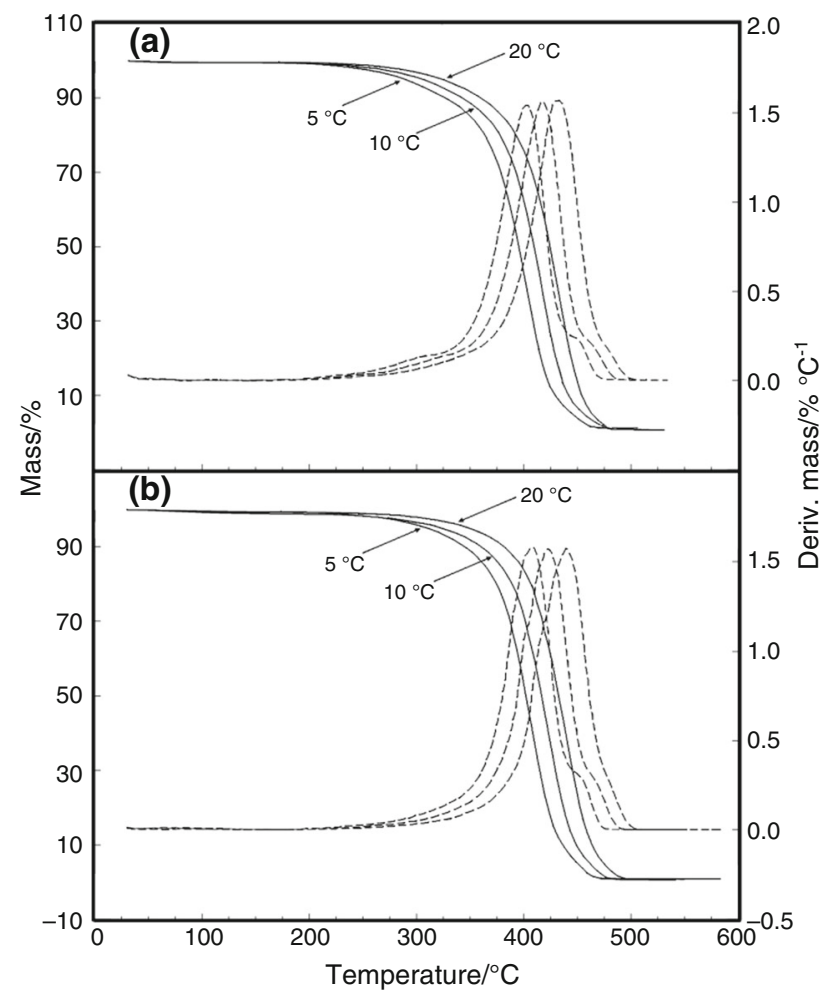

Fig. 4 TG/DTG curves of sweet pittosporum oil under nitrogen purge gas, with heating rates of 5,10 , and $20{ }^{\circ} \mathrm{C} \mathrm{min}{ }^{-1}$, sample mass of $5 \mathrm{mg}$ (a) and $20 \mathrm{mg}(\mathbf{b})$, both in platinum crucible

with mass of $20 \mathrm{mg}$, the energy of activation was not obtained because the TG curve with heating of $20{ }^{\circ} \mathrm{C} \mathrm{min}^{-1}$ has undergone a combustion process and due to this a temperature regression occurs when compared to curve with heating of $10{ }^{\circ} \mathrm{C} \mathrm{min}^{-1}$.

The relation between the activation energy versus conversion degree is shown in Fig. 6. As can be seen in the nitrogen purge gas that the kinetic behaviors are the same,

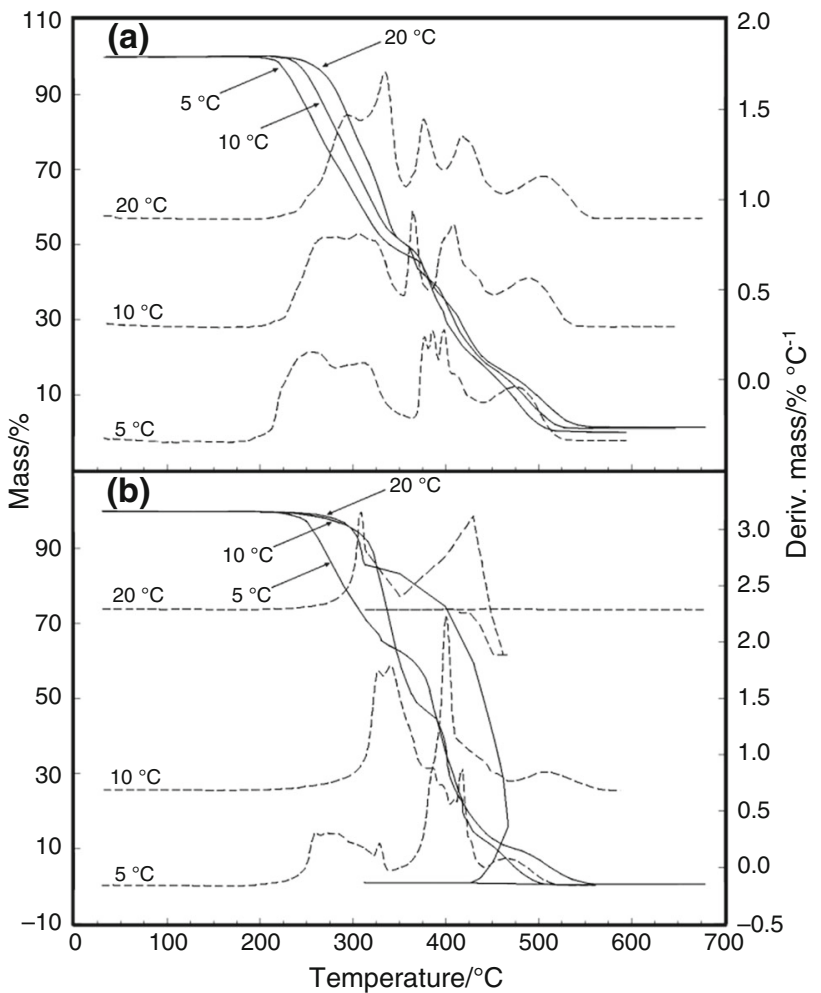

Fig. 5 TG/DTG curves of sweet pittosporum oil under oxygen purge gas, with heating rates of 5,10 , and $20{ }^{\circ} \mathrm{C} \mathrm{min}{ }^{-1}$, sample mass of $5 \mathrm{mg}$ (a) and $20 \mathrm{mg}$ (b), both in platinum crucible

while for analysis under oxygen purge gas, the kinetic value decreases. In previous papers, we consider that the oils can have different behaviors during heating due the oxidation of unsaturated fatty acids, with the formation of several products, which can produce alterations in kinetic behavior [13-15]. Therefore, the relationship between the activation energy and sample mass allows a better evaluation of the oils. 


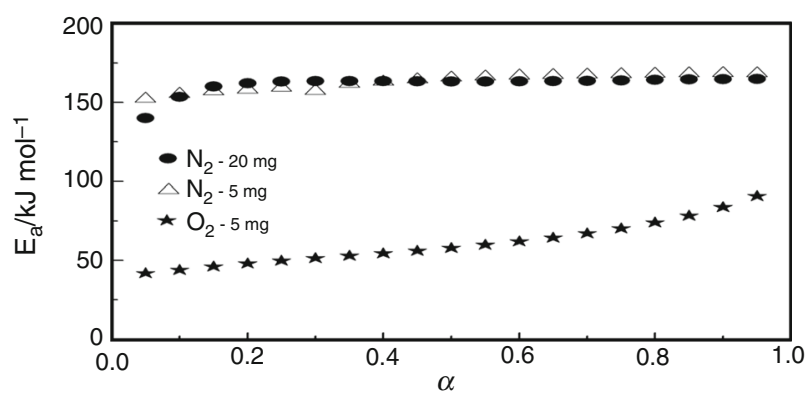

Fig. 6 Activation energy $v s$ conversion degree under nitrogen and oxygen purge gases

\section{Conclusions}

The results of gas chromatographic analysis showed that this oil has a high amount of unsaturated fatty acids, which corresponds to around $96 \%$. The extracted oil of sweet pittosporum seeds can be recommended for utilization as food, but after treatment for removing the less toxic antinutrients, and with special attention to eicosatrienoic acid (C20:3n3). It is necessary to carry out in vivo studies to confirm their harmlessness. The DSC curves under cooling/heating show there were two crystallization peaks and also others thermal asymmetric events, which were attributed to the presence of the several components of this oil.

The TG/DTG curves under oxidant and also in an inert purge gases allows monitoring the profiles of TG curves with two sample masses and several heating rates. In this work, also it was possible to verify that the activation energy under nitrogen gas is similar to both samples' masses. The activation energy of this oil under oxygen purge with sample mass of $20 \mathrm{mg}$ was not obtained due to combustion of this sample. Besides, the activation energy behavior with sample of $5 \mathrm{mg}$ was lower than that in nitrogen purge, which was attributed to the reaction of the oil with the oxygen gas.

\section{References}

1. Bellingham PJ, Tanner EVJ, Healey JR. Hurricane disturbance accelerates invasion by the alien tree Pittosporum undulatum in Jamaican montanera in forests. J Veg Sci. 2005;2005(16):675-84.

2. Mendes MD, Lima AS, Trindade H, Correia AID, Barroso JG, Pedro LG, Figueiredo AC. ISSR molecular characterization and leaf volatile sanalysis of Pittosporum undulatum Vent. naturalized in the Azores archipelago (Portugal). Ind Crops Prod. 2011;33:710-9.

3. Silva LM, Hasse I, Moccelin R, Zboralski AR. Arborização de vias públicas e a utilização de espécies exóticas: o caso do bairro centro de Pato Branco/PR. Scientia Agraria. 2007;8:47-53.
4. Mielke EC, Bonato RR, Negrelle Cuquel FL, Lima WP. Espécies exóticas invasoras arbóreas no parque da Barreirinha em Curitiba: registro e implicações. Ciência Florestal. 2015;25:327-36.

5. Mendes SAC, Mansoor TA, Rodrigues A, Armas JB, Ferreira MJU. Anti-inflammatory guaiane-type sesquiterpenes from the fruits of Pittosporum undulatum. Phytochemistry. 2013;95:308-14.

6. Higuchi R, Fujioka T, Iwamoto M, Komori T, Kawasaki T, Lassak E. Triterpenoid saponins from leaves of Pittosporum undulatum. Phytochemistry. 1983;22:2565.

7. Mendes MD, Lima AS, Trindade H, Correia AID, Barroso JG, Pedro LG, Figueiredo AC. ISSR molecular characterization and leaf volatiles analysis of Pittosporum undulatum Vent. naturalized in the Azores archipelago (Portugal). Ind Crops Prod. 2011;33:710-9.

8. Folch J, Lees M, Sloane-Stanley G. A simple method for the isolation and purification of total lipids from animal tissues. J Biol Chem. 1957;226:497-509.

9. Hartman L, Lago RC. Rapid preparation of fatty acid methyl esters from lipids. Lab Pract. 1973;22(494):475-6.

10. Kobelnik M, Fontanari GG, Soares R, et al. Study of the thermal behavior of bicuíba oil (Virola bicuyba). J Therm Anal Calorim. 2014;115:2107-13.

11. Ferreira LMB, Kobelnik M, Regasini LO, Dutra LA, Bolzani VS, Ribeiro CA. Synthesis and evaluation of the thermal behavior of flavonoids. J Therm Anal. 2017;127:1605-10.

12. Kobelnik M, Fontanari GG, Marques MR, Areas JAG, Franzin BT, Pastre IA, Fertonani FL. Thermal and kinetic studies of white lupin (Lupinus albus) oil. J Therm Anal Calorim. 2017. doi: 10. 1007/s10973-017-6468-0.

13. Kobelnik M, Cassimiro DL, Santos Dias D, Ribeiro CA, Crespi MS. Thermal behavior of araçá oil (Psidium cattleianum Sabine). J Therm Anal Calorim. 2012;108:1281-6.

14. Kobelnik M, Fontanari GG, Cassimiro DL, Ribeiro CA, Crespi MS. Thermal behavior of coffee oil (Robusta and Arabica species). J Therm Anal Calorim. 2013;115:2045-52.

15. Kobelnik M, Fontanari GG, Marques MR, Ribeiro CA, Crespi MS. Thermal behavior and chromatographic characterization of oil extracted from the nut of the Butia (Butia capitata). J Therm Anal Calorim. 2016;123:2517-22.

16. Capela JMV, Capela MV, Ribeiro CA. Nonisothermal kinetic parameters estimated using nonlinear regression. J Mathem Chem. 2009;45:769.

17. Vyazovkin S, Chrissafis K, Di Lorenzo ML, Koga N, Pijolat M, Roduitf B, Sbirrazzuoli N, Suñol JJ. ICTAC Kinetics Committee recommendations for collecting experimental thermal analysis data for kinetic computations. Therm Acta. 2014;590:1-23.

18. Ledeti I, Vlase G, Vlase T, Fulias A. Kinetic analysis of solidstate degradation of pure pravastatin versus pharmaceutical formulation. J Therm Anal Calorim. 2015;121:1103-10.

19. Zhang S, Wang S, Huang Z, Li Y, Tan Z. A kinetic analysis of thermal decomposition of polyaniline and its composites with rare earth oxides. J Therm Anal Calorim. 2015;119:1853-60.

20. Du R, Wu K, Zhang L, She Y, Xu D, Chao C, Qin X, Zhang B. Thermal behavior and kinetic study on the pyrolysis of Shenfu coal by sectioning method. J Therm Anal Calorim. 2015. doi: 10. 1007/s10973-016-5475-X.

21. Kobelnik M, Bernabé GA, Ribeiro CA, Capela JMV, Fertonani FL. Decomposition kinetics of iron (III)-diclofenac compound. J Therm Anal Calorim. 2009;97:493-6.

22. Miwa TK. Jojoba oil wax esters and derived fatty acids and alcohols: gas chromatographic analyses. J Am Oil Chem Soc. 1971;48:259-64.

23. Kikukawa H, Sakuradani E, Nishibaba Y, Okuda T, Ando A, Shima J, Shimizu S, Ogawa J. Production of cis-11-eicosenoic acid by Mortierella fungi. J Appl Microb. 2015;118:641-7. 
24. Martinez-Herrera J, Siddhuraju P, Francis G, Dávila-Ortız G, Becker K. Chemical composition, toxic/antimetabolic constituents, and effects of different treatments on their levels, in four provenances of Jatropha curcas L. from Mexico. Food Chem. 2006;96:80-9.

25. Avato P, Rosito I, Papadia P, Fanizzi FP. Cyanolipid-rich seed oils from Allophylus natalensis and A. dregeanus. Lipids. 2005;40:1051-6.

26. Yamanaka W, Clemans GW, Hutchinso ML. Essential fatty acids deficiency in humans. Prog Lipid Res. 1980;19:187-215.

27. Levy E, Garofalo C, Rouleau T, Gavino V, Bendayan M. Impact of essential fatty acid deficiency on hepatic sterol metabolism in rats. Hepatology. 1996;23:848-57.

28. Niinivirta K, Isolauri E, Laakso P, Linderborg K, Laitinen K. Dietary counseling to improve fat quality during pregnancy alters maternal fat intake and infant essential fatty acid status. J Nutr. 2011;141:1281-5.

29. Cafrey BB. Jonsson HTJr. Role of essential fatty acids in cutaneous wound healing in rats. Fed Proc. 1979;38:236.

30. Hamazaki T, Nagasawa T, Hamazaki K, Itomura M. Inhibitory effect of 5,8,11-eicosatrienoic acid on angiogenesis. Prostag Leukot Essent Fat Acids. 2012;86:221-4.

31. Orr SK, Palumbo S, Bosetti F, Mount HT, Kang JX, Greenwood CE, Ma DWL, Serhan CN, Bazinet RP. Unesterified docosahexanoic acid in protective in neuroinflamation. $\mathrm{J}$ Neurochem. 2013;127:378-93.

32. Gil-Campos M, DalmauSerra J. Importancia del ácido docosahexaenoico (DHA): funciones y recomendaciones para su ingesta en la infância. Anales Pediatría. 2010;73:142e1-8.
33. Lordan SR, Paul Ross RP, Stanton C. Marine bioactives as functional food ingredients: potential to reduce the incidence of chronic diseases. Mar Drugs. 2011;9:1056-100.

34. Ribeiro APB, Grimaldi R, Gioielli LA, Santos AO, Cardoso LP, Gonçalves LAG. Thermal behavior, microstructure, polymorphism, and crystallization properties of zero trans fats from soybean oil and fully hydrogenated soybean oil. Food Biophys. 2009;4:106-18.

35. Gouveia de Souza A, Oliveira Santos JC, Conceição MM, Dantas Silva MC, Prasad S. A thermoanalytic and kinetic study of sunflower oil. Braz J Chem Eng. 2004;21:265-73.

36. Vecchio S, Campanella L, Nuccilli A, Tomassetti M. Kinetic study of thermal breakdown of triglycerides contained in extravirgin olive oil. J Therm Anal Calorim. 2008;91:51-6.

37. Belitz HD, Grosch W, Schieberle P. Food chemistry. 4th ed. Berlin: Springer; 2009.

38. Knothe G, Dunn RO. A comprehensive evaluation of the melting points of fatty acids and esters determined by differential scanning calorimetry. J Am Oil Chem Soc. 2009;86:843-56.

39. Liang G, Xu J, Liu L. QSPR analysis for melting point of fatty acids using genetic algorithmbased multiple linear regression (GA-MLR). Fluid Phase Equil. 2013;353:15-21.

40. Mendonca ARV, Souza SMAU, Valle JAB, Souza AAU. Thermogravimetric analysis and kinetic study of pyrolysis and combustion of residual textile sludge. $\mathrm{J}$ Therm Anal Calorim. 2015;121:807-14.

41. Chew JJ, Doshi V, Yong ST, Bhattacharya S. Kinetic study of torrefaction of oil palm shell, mesocarp and empty fruit bunch. J Therm Anal Calorim. 2016. doi:10.1007/s10973-016-5518-3. 